\section{ECONOMICS}

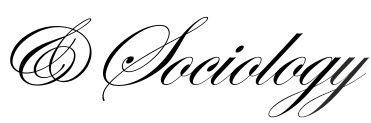

Vu, M. H. \& Nwachukwu, C. (2021). Entrepreneurial alertness and profitability of micro firms: the role of risk-taking. Economics and Sociology, 14(4), 107-117. doi:10.14254/2071-789X.2021/14-4/6

\title{
ENTREPRENEURIAL ALERTNESS AND PROFITABILITY OF MICRO FIRMS: THE ROLE OF RISK-TAKING
}

\author{
Hieu Minh Vu \\ $V$ an Lang University \\ Ho Chi Minh, Vietnam \\ E-mail:bieu.vm@vlu.edu.vn \\ ORCID 0000-0001-9525-2013 \\ Chijioke Nwachukwu* \\ Horizons University Paris, France; \\ Department of Financial \\ Technologies South Ural State \\ University Chelyabinsk, \\ Russian Federation \\ E-mail:nvacbakvu@@,susu.ru; \\ cesogwa.nwachukwn@,buparis.eu \\ ORCID 0000-0002-7982-2810 \\ *Corresponding author
}

Received: March, 2021

1st Revision: October, 2021

Accepted: November, 2021

\begin{abstract}
This study provides insights on entrepreneurial alertness (EA), risk-taking and profitability of micro-sized firms. The direct effects of entrepreneurial alertness on profitability, risk-taking on entrepreneurial alertness and the moderating mechanism of risk-taking are assessed. This research uses surveys completed by micro-sized firms in Ghana. Hypotheses were developed based on the literature review and were validated using data from 150 firms. It was observed that entrepreneurial alertness has significant influence on the profitability of microfirms. Similarly, risk-taking has a predictive impact on entrepreneurial alertness. The connection between entrepreneurial alertness and profitability is not enhanced when risk-taking is added as a moderator. Theoretically, our paper adds to the entrepreneurship literature by using the contingency theory to explain the moderating impact of risk-taking on the entrepreneurial alertnessprofitability relationship. Further, the study informs entrepreneurs in developing countries who operate in challenging and volatile business environments of the importance of alertness and risk-taking to profitability.
\end{abstract}

Keywords: risk taking, entrepreneurial alertness, profitability.
JEL Classification: D02, O17, P31
DOI: $10.14254 / 2071-$

789X.2021/14-4/6

\section{Introduction}

Nowadays, entrepreneurial alertness has emerged as a crucial factor for firms' success, especially microfirms. Entrepreneurship creates jobs, wealth, and economic growth (Nwachukwu et al., 2017). In this context, entrepreneurial alertness enables firms to create value from opportunities. These value-creating activities could be in terms of creating new products or establishing a new venture. Roundy et al. (2017) posit that alertness focuses on entrepreneurial opportunities that others cannot see but that is obvious to those who are alert. Most of the studies on entrepreneurial alertness focused on organizational outcomes in developed economies (e.g.Amato et al., 2016; Uy et al., 2015). Empirically, the literature relating entrepreneurial alertness to performance (especially profitability) in developing economy contexts is lacking (Adomako et al., 2018). 
Following Zahra (2007), 'context is important in entrepreneurship theory development'. Thus, it is crucial to investigate the subject from a developing market perspective to enhance the understanding of the entrepreneurial alertness-profitability relationship. Risk-taking entails the uncertainty that emerges from behaving entrepreneurially (Donkoh \& Nwachukwu, 2018). Research on the risk-taking-performance relationship is mixed. For instance, (Karacaogl et al., 2013; Jalali et al., 2014; Anlesinya et al., 2015) reported positive relationship, whereas (Gürbüz \& Aykol, 2009; Hughes \& Morgan, 2007) suggest otherwise. Additionally, the survey of previous literature suggests that the direct impact of risktaking on entrepreneurial alertness is relatively unknown. Likewise, the moderating mechanism of risk-taking on entrepreneurial alertness and profitability is unclear. Besides, authors respond to other researchers'call (e.g. Montiel-Campos, 2018; Lee et al., 2011) that passion and alertness should be examined with other variables within the entrepreneurial process. Indeed, risk-averse firms may not be willing to take advantage of opportunities in their environment. Arguably, risk-taking may constrain or enhance entrepreneurial alertness to opportunities. It is proposed that the ability to take risks (risk-taking) may strengthen the relationship between entrepreneurial alertness and profitability in microfirms located in developing markets. Given that the direct impact of entrepreneurial alertness and the moderating effect of risk-taking on profitability in developing countries, especially Ghana is relatively unknown. Moreover, profitability is important for microfirms' sustainability. Thus, this study is timely and relevant. It is important therefore to address this gap. Thus, this paper fills the gap in entrepreneurship research by proposing that risk-taking dimension of entrepreneurial orientation could help explain the connection between entrepreneurial alertness and profitability. Therefore, examining the impact of entrepreneurial alertness on profitability, risk-taking on entrepreneurial alertness and the moderating role of risk-taking in the relationship between entrepreneurial alertness and profitability can provide useful insights on this important research issue in firms. The positive impact of microfirms on developed and developing economies is well documented in the literature. Thus, examining this research issue in microfirms will provide insights into entrepreneurial alertness, risk-taking, profitability relationship and the implication it holds for developing economies and Ghana in particular. The paper is structured as follows. The theoretical foundation and overview of the literature on entrepreneurial alertness and risk-taking, and the research hypotheses are presented. Next section reveals the methodology used. The section following presents the research results. The research findings and relevant contributions to theoretical knowledge, managerial practice, limitations and suggestions for future research are presented in the final section.

\section{Literature review}

From the resource-based theory RBT perspective, entrepreneurial alertness can drive the profitability of micro firms. The RBT suggests that resources are assets owned or controlled by entrepreneurs to sense and seize market opportunities (Wade \& Hulland, 2004). Firms can create economic value using a bundle of well-managed resources (Nwachukwu et al. 2018). These resources are unique and are not the same among entrepreneurs (Helfat \& Peteraf, 2015). The difference in performance is explained by entrepreneurs' ability to create, improve and change resources (Teece, 2012; Zahra et al., 2006). In light of this, authors align with the submission of (Helfat \& Peteraf, 2015; Messersmith \& Wales, 2013) that alertness is a cognitive resource that enables entrepreneurs to identify opportunities before others. Superior performance is likely to depend on an entrepreneur's ability to leverage opportunity before others (Teece, 2012) and not by just possessing cognitive resource (Adomako et al., 2018). Arguably, increased alertness may lead to better profits on the assumption that alert 
entrepreneurs can optimize business opportunities before others (Shane \& Venkataraman, 2000). By taking advantage of a new market opportunity, an alert entrepreneur can create value and enhance micro-sized firm profitability. Contingency theory CT suggests that contextual factors are important in understanding the effect of independent on dependent variables (e.g. Chandler, 1962). Empirically, the CT has been used to explain the moderation mechanism of risk propensity (Cui et al., 2016), organizational structure (Nwachukwu \& Chladkova, 2019), networking capabilities (Adomako et al., 2018), policy (Nwachukwu et al., 2020); environmental munificence (Canan \& Dursun, 2015); and employee satisfaction (e.g. Fadeyi et al., 2018). Authors reason that entrepreneurial alertness in profitability context may differ due to risk-taking. The $\mathrm{CT}$ is an appropriate theory to explain the interaction effects of risk-taking in the relationship between entrepreneurial alertness and profitability of micro firms. Arguably, the link between entrepreneurial alertness and profitability may be enhanced by the risk-taking behaviour of an entrepreneur.

\section{Entrepreneurial alertness}

Entrepreneurial alertness enables an entrepreneur to identify and exploit opportunities ahead of others and exploiting opportunities will lead to entrepreneurial profit (Alvarez \& Barney, 2007). Alertness denotes a "state of mind" that is always open to spotting opportunities (Valliere, 2013). Gaglio and Katz, (2001) contend that alert entrepreneurs are able to look for changes in the business environment, identify and optimise opportunities. Kirzner (1979) asserts that alertness is the ability of an entrepreneur to exploit entrepreneurial opportunities and offer new products or services to the market. Kirzner (1999) submitted that alertness can add value to a business because it assists entrepreneurs to recognise trends and opportunities that others overlooked. Arguably, entrepreneurs may recognize an opportunity in their business environment, but profitability can only be achieved when they act to leverage the opportunity before competitors (Shane and Venkataraman, 2000). Roundy et al. (2017) opined that alert entrepreneur decision making process can influence performance. Entrepreneurs in Ghana may hardly spot and leverage opportunities because of a low level of entrepreneurial alertness (Adomako et al., 2018). In Ghana, Adomako et al., (2018) found that alertness and networking capabilities explain the performance of new ventures in Ghana. Arguably, entrepreneurial alertness through sensing and exploiting entrepreneurial opportunities can influence micro firm profitability. Authors hypothesize;

H1. Entrepreneurial alertness will lead to higher profitability for micro-sized firms.

\section{Risk-taking and entrepreneurial alertness}

Empirically, studies on risk-taking are mixed and inconsistent. Researchers like Anlesinya et al. (2015), Karacaogl et al. (2013), Jalali et al. (2014) and Neneh (2011), demonstrated that risk-taking is linked to performance in different contexts. Whereas, Gürbüz and Aykol (2009), Hughes and Morgan (2007) found a negative relationship. Risk-averse firms avoid market opportunities which make them underperform (Hughes and Morgan (2007). Risktaking involves identifying and managing risks (Ogunsiji \& Kayode, 2010). Cui et al. (2016) observed that entrepreneurial alertness to ideas significantly influences risk-taking, a measure of entrepreneurial capabilities. To our knowledge, no study has uncovered the impact of risktaking behaviour on entrepreneurial alertness, this informs the reason for scare literature on the subject. Arguably microfirms that are not risk-averse are able to spot and take advantage of opportunities ahead of others. On the other hand, risk-averse firms may not be able to exploit opportunities in their business environment. We hypothesize that; 
H2. Risk-taking has a positive and significant influence on alertness.

\section{Moderating Effect of Risk-taking on Entrepreneurial Alertness and Profitability}

The effectiveness of EA and profitability may be contingent on the risk-taking behaviour of a firm. Cui et al. (2016) affirm that risk propensity moderates the impact of alertness on business ideas and entrepreneurial capabilities. Arguably, firms that encourage risk-taking behaviour are better positioned to exploit opportunities, whereas firms that do not encourage risk-taking may fail to take advantage of business opportunities (Neck \& Manz,1996). Additionally, recognising and exploiting opportunities requires risk-taking (Kohtamäki, et al., 2019). Arguably, benefiting from entrepreneurial alertness, micro-sized firms need moderate to high level of risk-taking. In this context, risk-taking may strengthen or restrict the effect of EA on the profitability of micro firms. Authors reason that the higher the risk-taking capacity, the stronger the impact of EA on profitability. The interaction effect of risk-taking on entrepreneurial alertness and profitability of micro-sized firms in developing countries such as Ghana will be significant. Authors hypothesized that;

H3. Risk-taking moderate the effect of entrepreneurial alertness on the profitability of micro-sized firms

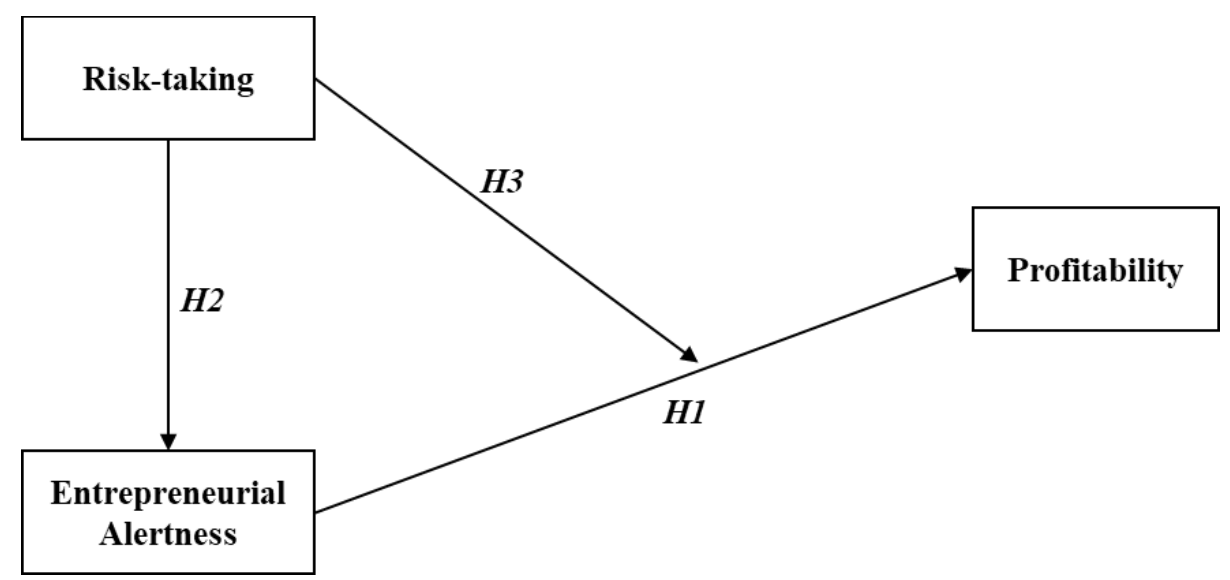

Figure 1. Research model

Source: Authors, 2020

\section{Methodological approach}

\subsection{Sample data and demographics}

This study used data collected from micro-sized firms in the handicraft manufacturing sector in Ghana. The sector provides a large number of jobs to rural dwellers during "'offfarming seasons" (Essabra-Mensah, 2017). Ghana is a leading country in Africa in terms of GDP growth rate $(8.14 \%)$ (The World Bank, 2017). Data collection took place from December 2019 to February 2020 at the Art centre and Oxford street, Osu in the Greater Accra region. The locations are popular with tourists who are often the target market. The list of the firms was retrieved from the Ghana export promotion authority and Ghana chamber of commerce databases. 200 micro-firms were randomly selected. 150 completed surveys from business owners were used in the analysis. This represents $75 \%$ response rate which is sufficient (Bryman \& Bell, 2015). A sample of at least 30 per group is sufficient for correlational studies (Bryman, 2004). Hence 150 responses are above the recommended sampling frame. A single 
industry was investigated to avoid the potential noise that may arise from multiple industries (Kohtamäki et al., 2019; Parida \& Örtqvist, 2015; Patel et al., 2015).

\subsection{Measures and analytical approach}

Tang et al. (2012) EA scale was adapted and modified to suit our study. Five items were used to assess entrepreneurial alertness. To measure risk-taking, authors adapted Covin and Slevin's (1989), which was also used in the work of Donkoh \& Nwachukwu, (2018). Three items were used to evaluate risk-taking. one question was used to measure profitability. Singleitem measures have high predictive validity as multiple question scales (Bergkvist \& Rossiter, 2009). Entrepreneurial alertness and risk-taking were evaluated based on respondents' perceptions. A 5-point Likert scale; " $1=$ strongly agree to $5=$ strongly disagree" was used. Profitability was assessed using a 5-point Likert scale ranging from "1 (below average) to 5 (above average)', Micro firms in developing countries are characterised by lack of objective performance data. Thus, the reason for using a subjective measure based on owner's perception. Computed Cronbach's alpha (0.74) show that the instrument is consistent and reliable (Zikmund et al., 2013). The opinion of experts was sought on face validity, comprehensiveness and coherency of the measurement scale. Correlation analysis was used to evaluate the direction and strength of the relationship between the variables. Authors used regression to determine the level of significance and predictability of EA on profitability and risk-taking on entrepreneurial alertness. Hierarchical regression was used to test the interaction of risk-taking on entrepreneurial alertness and profitability. (SPSS 25) was employed for data analyses.

\subsection{Handling common method bias (CMB)}

The owner-managers can give reliable information on the subject. Respondents anonymity was assured to reduced fear and lack of interest (Conway \& Lance, 2010; Podsakoff et al., 2003). Additionally, "correlations between the variables that is higher than 0.9 indicate common method bias"' (Bagozzi et al., 1991). Entrepreneurial alertness and risk-taking have the highest correlation (0.535), which show that there is no CMB problem (see table 2).

\section{Conducting research and results}

$80(53.3 \%)$ of the firms have between 1 to 10 employees, $46(30.7 \%)$ have between 11 20 employees, 21 (14\%) between 21-30 employees and $3(2 \%)$ have between 31-40. 96(64\%) respondents have been operating their firms between 0 and 5years, $45(30 \%)$ respondents have been running their firm between 6 to 10 years, $9(6 \%)$ participants have firms that are between 11- 40-year-old.

Table 1 shows that the respondents agreed with questions concerning entrepreneurial alertness: "I am able to identify opportunities for value creation (mean score, 4.05)", "I develop creative and purposeful ideas (mean score, 3.91)", "'I develop a vision to turn opportunities into action (mean score, 4.39)",', I make most of opportunities in my business climate (mean score, 4.38)", "'I assess the consequences and impact of opportunities and actions (mean score, 4.07)'”. In terms of risk-taking, the respondents agreed with the questions asked: 'I have a strong proclivity for high-return high-risk project (mean score, 4.00)', ' 'I adopt a bold, aggressive posture in order to maximize the probability of exploiting potential opportunities (mean score, 4.06)', 'I encourage risk-taking behaviours (mean score, 4.06)'". 
Table 1. Items and their mean and standard deviations

\begin{tabular}{ccc}
\hline Questionnaire items & Mean & Std. dev \\
\hline EA1 & 4.05 & 0.915 \\
\hline EA2 & 3.91 & 0.983 \\
\hline EA3 & 4.39 & 0.969 \\
\hline EA4 & 4.38 & 0.967 \\
\hline EA5 & 4.07 & 1.041 \\
\hline RT1 & 4.00 & 1.129 \\
\hline RT2 & 4.06 & 0.899 \\
\hline RT3 & 4.06 & 0.899 \\
\hline
\end{tabular}

$\mathrm{N}=150$, Cronbach alpha $=0.74$

Source: Authors, 2020

Table 2. Correlation results

\begin{tabular}{lccc}
\hline Profitability & Entrepreneurial Alertness & Risk-taking & \\
\hline Profitabililty & 1 & & \\
\hline $\mathrm{r}$ & & $0.267^{* *}$ & $0.162^{*}$ \\
\hline Sig. (2-tailed). & & 0.001 & 0.047 \\
\hline \multicolumn{2}{l}{ Entrepreneurial alertness } & & \\
\hline $\mathrm{r}$ & $0.267^{* *}$ & 1 & $0.535^{* *}$ \\
\hline Sig. (2-tailed). & 0.001 & & 0.000 \\
\hline & & & \\
\hline Risk-taking & & $0.535^{* *}$ & 1 \\
\hline $\mathrm{r}$ & $0.162^{*}$ & 0.000 & \\
\hline Sig. (2-tailed). & 0.047 & & \\
\hline N 150 & & & \\
\hline
\end{tabular}

$\mathrm{N}=150$

Source: Authors, 2020

Table 3. Regression results

Ent. Alertness/profitabilityRisk-taking/Entrepreneurial alertnessEntAlertnessXrisk-taking

\begin{tabular}{llll}
\hline $\mathrm{R}^{2}$ & 0.0710 .286 & & \\
\hline$\beta$ & 0.267 & 0.535 & \\
\hline $\mathrm{F}$ & 11.341 & 59.349 & \\
\hline $\mathrm{t}$ & 3.368 & 7.704 & 0.000 \\
\hline $\mathrm{P}$-value & 0.001 & 0.000 & 0.999 \\
\hline$\Delta \mathrm{R}^{2}$ & & & 3.579 \\
\hline$\Delta$ Sig. & & 1.350 & \\
\hline Durbin Watson & 1.900 & &
\end{tabular}

$\mathrm{N}=150$

Source: Authors, 2020 
The results presented in Table 3 , indicate that $(\beta)$ for entrepreneurial alertness on microsized profitability $(\mathrm{H} 1)((\beta=0.267, \mathrm{p}$-value $=0.001)$, suggest that a greater level of entrepreneurial alertness leads to higher profitability for micro-sized firms. Entrepreneurial alertness with $(\mathrm{R} 2=0.071)$ explains only $7 \%$ variation in profitability of micro-sized firms. This implies that other factors not included account for $93 \%$ variations in the profitability of micro-sized firms. Consistent with our expectation, the coefficient value $(\beta)$ for risk-taking on entrepreneurial alertness (Hypothesis 2) is (0.535) with a p-value of 0.000 . This result is significant. Risk-taking has a positive and significant influence on entrepreneurial alertness. Risk-taking ( $\mathrm{R} 2=0.286$ ) accounts for $28.6 \%$ of variation in entrepreneurial alertness. Other variables excluded from this study account for $71.4 \%$ variations in entrepreneurial alertness. The interaction effect of risk-taking on entrepreneurial alertness and profitability has a zero effect and is not statistically significant $(\Delta \mathrm{R} 2=0.000, \Delta \mathrm{Sig} .=0.999)$. This implies that $\mathrm{H} 3$, risk-taking moderate the effect of EA on the profitability of micro-sized firms is not supported. The effect of EA on profitability is not stronger when levels of risk-taking are higher. The variance inflation factor (3.579) is less than 5 (Ringle et al., 2015), suggest the absence of multicollinearity. Also, the Durbin-Watson test range between 1.350-1.900 indicates the absence of autocorrelation in our mode.

Table 4. Hypotheses test decision

\begin{tabular}{ccc}
\hline Hypotheses & P-value & Remark/decision \\
\hline H1 & 0.001 & Accept \\
\hline H2 & 0.000 & Accept \\
\hline H3 & 0.999 & Reject \\
\hline
\end{tabular}

Source: Authors, 2020

\section{Conclusion}

This study uncovers the effect of EA on profitability, risk-taking on EA, and the moderating impact of risk-taking. Findings from the study indicate that entrepreneurial alertness influence the profitability of micro firms. The results suggest that an increase in the level of EA can make firms take advantage of entrepreneurial opportunities, which can lead to higher profitability. It can be argued that identifying and turning opportunities into action facilitates value creation. As such, for micro-sized firms that want to achieve higher profits, alertness to entrepreneurial opportunities predicts their profitability. Empirically, this result aligns with findings of previous related studies (e.g. Roundy et al., 2017; Adomako et al., 2018). Thus, enhancing the understanding of the importance of alertness to opportunities and profitability relationship nexus. The results from the study further suggest that risk-taking behaviour enable firms to spot and seize entrepreneurial opportunities ahead of others. Furthermore, firms that adopt bold and aggressive positions can leverage entrepreneurial opportunities. In developing countries such as Ghana, the business climate is characterized by high level of uncertainties and risks. In such a context, firms with risk-taking capacity may be able to see opportunities and take necessary action ahead of their peers. This result affirms the claim of Hughes and Morgan (2007), who reported that risk-averse firms are not able to exploit market opportunities, which lead to poor performance. Furthermore, risk-taking does not moderate the entrepreneurial alertness-profitability nexus. Thus, the effect of EA on profitability is not enhanced when risk-taking is added as a moderator. 


\section{Theoretical contributions}

The study has contributed to the debate on entrepreneurship as it has shown how entrepreneurial alertness contributes to improved micro-sized firm profitability as well as how risk-taking contributes to entrepreneurial alertness. Additionally, this study enriches entrepreneurship literature by using the $\mathrm{CT}$ to investigate the moderating role of risk-taking on the entrepreneurial alertness-profitability relationship. In light of Resource-Based Theory, EA is a cognitive resource that influences the profitability of micro-sized firms in Ghana. Indeed, the study provides insight into the direct benefit of risk-taking on entrepreneurial alertness.

\section{Study implications}

This study has implications for entrepreneurs in developing countries who operate in challenging and volatile business environments. Entrepreneurs in countries like Ghana can use entrepreneurial alertness and risk-taking to improve their profitability. A high level of alertness to opportunity is a predictor of micro-sized handicraft manufacturing firms profitability in Ghana. By recognising the importance of alertness to entrepreneurial opportunities, firms can achieve higher profitability. Additional, micro firms should give attention to hiring people who can assess and leverage the opportunities in their environment. The idea that risk-taking is directly related to alertness to entrepreneurial opportunities should be of interest to micro firms in Africa especially Ghana. Micro-sized firms should encourage risk-taking behaviour that can make them optimise opportunities that others fail to spot. On the other hand, less attention to entrepreneurial alertness may lead to poor profitability. This result suggests that the route between entrepreneurial alertness and firm profitability is straightforward in practice.

\section{Limitations and future research}

The limitations in the current paper provide an opportunity for more research. First, the study was conducted in a single industry and single country (micro-sized handicraft manufacturing firms in Ghana), which make it difficult to generalize the results across industries and countries. Nonetheless, future studies should focus on other industries and countries. Second, the study's relied on perceptual measures to operationalise the profitability of micro firms. Access to reliable objective secondary data in the context of micro-sized firms in developing countries is not available. Nevertheless, the entrepreneur's perception of performance is considered an important measure of performance (Powell, 1992). Scholars may use objective data to measure profitability where such data exist. Additionally, future studies should continue to test the effects of entrepreneurial alertness on other performance variables such as sales growth, market value etc. Researchers should continue to search for other moderating and mediating variables that can provide insights into the entrepreneurial alertnessperformance connection. Finally, researchers should give attention to entrepreneurial alertness and risk-taking, especially in the micro to medium-sized firms..

\section{References}

Adomako, S., Danso, A., Boso N., \& Narteh, B. (2018). Entrepreneurial alertness and new venture performance: facilitating roles of networking capability. international small business journal researching entrepreneurship, 36(5), 453-472.

Alvarez, S. A., \& Barney, J. B. (2007). Discovery and creation: alternative theories of entrepreneurial action. Strategic Entrepreneurship Journal, 1, 11-26.

Amato, C. A Baron R, Barbieri B., Bélanger, J. J \& Pierro, A. (2016). Regulatory modes and entrepreneurship: The mediational role of alertness in small business success. Journal of Small Business Management, 55(51), 27-42. 
Anlesinya, A., Eshun, P., \& Bonuedi, A. A. (2013). Entrepreneurial orientation dimensions and profitability nexus: evidence from microenterprises in the retail sector in a developing country. International Journal of Small Business and Entrepreneurship Research, 3(7), 79-87.

Bagozzi, R. P., Yi, Y. \& Phillips, L. W. (1991). Assessing construct validity in organizational research. Adm. Sci. Q., 36, 421-458.

Bergkvist, L., \& Rossiter, J. R. (2009). Tailor-made single-item measures of doubly concrete constructs. International Journal of Advertising, 28(4), 607-621.

Bryman, A. (2004). Social Research Methods, 2nd ed., Oxford University Press, Oxford.

Bryman, A. \& Bell, E. (2015). Business research methods. 4th ed. USA: Oxford University Press.

Canan, N. K. \& Dursun, B. (2015). Entrepreneurial Alertness in Turkey: Human and Social Capital Perspectives. International Journal of Business and Social Research, 5(4), 34-51.

Chandler, A. D. (1962). Strategy and Structure: Chapters in the History of the Industrial Enterprises. Cambridge, MA: MIT Press.

Conway, J. M. \& Lance, C. E. (2010). What reviewers should expect from authors regarding common method bias in organizational research. Journal of Business and Psychology, 25(3), 325-334.

Covin, J., \& Slevin, D. (1989). Strategic management of small firms in hostile and benign environments. Strategic Management Journal, 10(1), 75-87.

Cui, Y., Sun, C., Xiao, H. \& Zhao, C. (2016) How to become an excellent entrepreneur: The moderating effect of risk propensity on alertness to business ideas and entrepreneurial capabilities. Technol. Forecast. Soc. Change, 1-7. http://dx.doi.org/10.1016/j.techfore.2016.08.002

Donkoh, I. \& Nwachukwu, C. (2018). Relationship between risk-taking, innovativeness, proactiveness, and profitability of MSMEs in Ghana. Paper presented at the 22nd European Scientific Conference of Doctoral Students November 29, 2018, in Brno.

Essabra-Mensah, E. (2017, 10 13). Gov’t targets US\$1b annually from handicrafts sales. Retrieved from Business and Financial times: https://thebftonline.com/2017/economy/govt-targets-us1b-annually-from-handicraftssales/

Fadeyi, O., Oladele, J.K., \& Nwachukwu, C. (2018). Succession Planning and Job Commitment: Moderating Role of Employees' Satisfaction in Selected Beverages Companies in Lagos. Metropolis. Trends Economics and Management, 30(3), 21-36.

Gaglio, C. M. \& Katz, J. A. (2001). The psychological basis of opportunity identification: Entrepreneurial alertness. Small Business Economics, 16(2), 95-111.

Gürbüz, G., \& Aykol, S. (2009). Entrepreneurial management, entrepreneurial orientation and Turkish small firm growth. Management Research News, 32(4), 321- 336.

Helfat, C.E \& Peteraf, M. A. (2015). Managerial cognitive capabilities and the microfoundations of dynamic capabilities. Strategic Management Journal, 36(6), 831850.

Hughes, M., \& Morgan, R.E. (2007). Deconstructing the relationship between entrepreneurial orientation and business performance at the embryonic stage of firm growth. Industrial Marketing Management, 36, 651-661.

Jalali, A., Jaafar, M., Talebi, K., \& HJalim, A. S. (2014). The moderating role of bridging ties between risk-taking, proactiveness and performance: The evidence from Iranian SMEs. International Journal of Business and Management, 9(5), 74-87. 
Karaoglu, K., Bayrakdaroglu, A., \& San, F.B. (2013). The impact of corporate entrepreneurship on firms' financial performance: Evidence from Istanbul Stock Exchange firms. International Business Research, 6(1), 163-175.

Kirzner, I. M. (1999). Creativity and/or alertness: a reconsideration of the Schumpeterian entrepreneur. Review of Austrian Economics, 11, 5-17.

Kirzner, I. M (1979). Perception, opportunity, and profit. University of Chicago Press. Kwon S W and Arenius P (2010) Nations of entrepreneurs: A social capital perspective. Journal of Business Venturing, 25(3), 315-330.

Lee, L., Wong, P.K., Foo, M.D., \& Leung, A. (2011). Entrepreneurial intentions: the influence of organizational and individual factors. Journal of Business Venturing, 26(1), 124-136.

Messersmith, J.G., \& Wales, W.J (2013). Entrepreneurial orientation and performance in young firms: The role of human resource management. International Small Business Journal, 31(2), 115-136.

Montiel-Campos, H. (2018) The Entrepreneurial Passion-Entrepreneurial Alertness Relationship: the moderating role of a creative personality. Serbian Journal of Management, 13(2), 263 - 280.

Neck, C., \& Manz, C. (1996). Thoughtself-leadership: The impact of mental strategies training on employee cognition, behavior, and affect. Journal of Organizational Behavior, 17(5), 445-467.

Nwachukwu, C., \& Chladkova, H. (2019). Firm resources, strategic analysis capability and strategic performance: organisational structure as moderator. International Journal for Quality Research, 13(1), 75-94.

Nwachukwu, C., Zufan, P., \& Chladkova, H. (2020). Employee commitment to strategy implementation and strategic performance: organisational policy as moderator. International Journal of Business Excellence, 20(3), 398-418.

Nwachukwu, C., Chladkova, \& Olatunji, F. (2018). Strategy Formulation Process and Innovation Performance Nexus. International Journal for Quality Research, 12(1),147164.

Nwachukwu, C., Chladkova, H., \& Zufan, P. (2017). The relationship between Entrepreneurial orientation, entrepreneurial competencies, entrepreneurial leadership, and firm performance: A proposed model. Business Trends, 7(1), 3-16.

Ogunsiji, P., \& Kayode, W.L. (2010). Entrepreneurial Orientation as a Panacea for the Ebbing Productivity in Nigerian Small and Medium Enterprises: A Theoretical Perspective. International Business Research, 3(4), 192-199.

Parida, V., \& Örtqvist, D. (2015). Interactive effects of network capability: ICT capability, and financial slack on technology-based small firm innovation performance. Journal of Small Business Management, 53, 278-298.

Patel, P. C., Kohtamäki, M., Parida, V., \& Wincent, J. (2015). Entrepreneurial orientation asexperimentation and firm performance: The enabling role of absorptive capacity. Strategic Management Journal, 36(11), 1739-1749.

Podsakoff, P., MacKenzie, S., Lee, J., \& Podsakoff, N. (2003) Common method biases in behavioral research: A critical review of the literature and recommended remedies. Journal of Applied Psychology, 88, 879-903.

Powell, T.C. (1992) Organizational alignment as competitive advantage. Strategic Management Journal, 13, 119-134.

Ringle, C. M., Wende, S., \& Becker, J-M. (2015). SmartPLS 3. Bönningstedt: SmartPLS. Retrieved from http://www.smartpls.com 
Roundy, P. T., Harrison, D. A., Khavul, S., Pérez-Nordtvedt, L., \& McGee, J. E. (2017). Entrepreneurial alertness as a pathway to strategic decisions and organizational performance. Strategic Organization, $1-35$

Shane, S., \& Venkataraman, S. (2000). The promise of entrepreneurship as a field of research. Academy of Management Review, 25, 217-226.

Tang J., Kacmar, K. M., \& Busenitz, L. (2012). Entrepreneurial alertness in the pursuit of new opportunities, Journal of Business Venturing, 27, 7-94.

Teece D J (2012) Dynamic capabilities: Routines versus entrepreneurial action. Journal of Management Studies, 49(8), 1395-1401.

The World Bank. (2017, 06 02). Retrieved from GDP Growth: https://data.worldbank.org/indicator/NY.GDP.MKTP.KD.ZG?locations=GH

Uy, M. A., Chan, K., Sam, Y. L, Ho, M. H. R, \& Chernyshenko, O. S. (2015). Proactivity, adaptability and boundaryless career attitudes: The mediating role of entrepreneurial alertness. Journal of Vocational Behavior, 86, 115-123.

Valliere, D. (2013). Towards a schematic theory of entrepreneurial alertness. Journal of Business Venturing, 28, 430-442.

Wade, M., \& Hulland, J. (2004). The resource-based view and information systems research: Review, extension, and suggestions for future research. MIS quarterly, 28(1), 107-142.

Zahra, S. A. (2007). Contextualizing theory building in entrepreneurship research. Journal of Business venturing, 22(3), 443-452.

Zahra, S. A., Sapienza, H. J., \& Davidsson, P. (2006). Entrepreneurship and dynamic capabilities: A review, model and research agenda. Journal of Management Studies, 43(4), 917-955.

Zikmund, W. G., Babin, B. J., Carr, J. C., \& Griffin, M. (2013). Business research methods. 9th ed. USA: South-Western, Cengage Learning. 